\title{
A Phenomenology of the Liturgy of Maundy Thursday
}

\author{
Tamsin Jones
}

check for

updates

Citation: Jones, Tamsin. 2021. A Phenomenology of the Liturgy of Maundy Thursday. Religions 12: 608. https://doi.org/10.3390/rel12080608

Academic Editor: Christina

M. Gschwandtner

Received: 15 July 2021

Accepted: 3 August 2021

Published: 5 August 2021

Publisher's Note: MDPI stays neutral with regard to jurisdictional claims in published maps and institutional affiliations.

Copyright: (C) 2021 by the author. Licensee MDPI, Basel, Switzerland. This article is an open access article distributed under the terms and conditions of the Creative Commons Attribution (CC BY) license (https:// creativecommons.org/licenses/by/ $4.0 /)$.
Department of Religious Studies, Trinity College, Hartford, CT 06106, USA; Tamsin.jones@trincoll.edu

\begin{abstract}
In this article, I propose a phenomenological analysis of the liturgy of Maundy Thursday, as it is celebrated in the contemporary Anglican Church of Canada. As an example of liturgy, Maundy Thursday is particularly generative for phenomenological description because of its affective range and drama. A participant in the liturgy is given the opportunity to experience a combination of grief, lament, remorse, joy, thanksgiving, kindness and compassion, care for the body, vulnerability and humility, as well as fear and confusion. Situated on the threshold between Lent and Easter, it is a richly complex moment in the liturgical year and combines, in a creative and affective tension, celebration with mourning, order with chaos, and love and service with betrayal and repentance.
\end{abstract}

Keywords: phenomenology; Maundy Thursday; Anglican; liturgy

\section{Introduction}

In this article, I propose a phenomenological analysis of the liturgy of Maundy Thursday, as it is celebrated in the contemporary Anglican Church of Canada. Rather than rely on other philosophical or theological analyses of this liturgy, as much as possible this article will draw primarily on the textual source and the performance of the liturgy itself in order to give a phenomenological description of the experience of the liturgy. Intentionally, then, there is relatively little engagement with other scholars in this article.

Maundy Thursday occurs during Holy Week and leads directly into the two holiest of Christian holy days, Good Friday and Easter. As an example of liturgy, Maundy Thursday is particularly generative for phenomenological description because of its affective range and drama. Situated on the threshold between Lent and Easter, it is a richly complex moment in the liturgical year and combines, in a creative and affective tension, celebration with mourning, order with chaos, and love and service with betrayal and repentance.

\section{Phenomenological Analysis of Liturgy}

Phenomenology is a method of philosophy which seeks to be attentive to, and descriptive of, lived experience. Such detailed description pays attention to the temporality, spatiality, and the embodied action and produced effect of the liturgy as much as, if not more than, an analysis of the textual meaning of it. For the most part, this paper focuses on such an analysis, relying primarily on a description of the liturgy itself, rather than drawing on theologies of the liturgy. ${ }^{1}$ As a method, phenomenology is less interested in claiming the truth or superiority of this or that liturgy or religious ritual than it is in providing a detailed and resonant description of what it is to experience a specific liturgy.

A phenomenological analysis considers more than the words of the liturgy; it also observes the ritual actions and material objects used in the liturgy. ${ }^{2}$ It also analyzes the temporality and spatiality of the service. For instant, where does it fit within the liturgical calendar? What season in the year is it? What time of day does it take place in? Thinking about the experience of the congregants, in what way does one's participation in the liturgy orient one to the past, as well as direct one to the future? How are people organized within the space and what does that placement signify about the order of the liturgical celebration and how does it impact their experience? What is the purpose of the orchestrated movements in a liturgy-how do they function and what do they convey? What are the 
differences in the bodily postures, movements, and placements of the priests in comparison with the congregants-when are they separated in position and movement, and when are they united? As I hope to show, the answers to each of these questions have a cumulative impact on a participant's experience of the liturgy.

By primarily attending to what Megan Macdonald has called the "unarticulated interactions" with the materiality of the liturgy rather than solely the textual aspects of it, the aim of phenomenological analysis encompasses more than the theological: it also seeks to undercover the ways in which participation in the performance of the liturgy produces a particular affective impact (Macdonald 2012, p. 31). Thus, a phenomenological analysis of a liturgy is also keenly interested in what affective responses are cultivated through participation in it: joy, fear, gratitude, humility, veneration, vulnerability, comfort, grief, guilt, or a complex combination of them?

Liturgy "opens a world" for the participant (Gschwandtner 2019, p. 28); ${ }^{3}$ it encompasses a cosmology and a temporality, places the individual and the community within that world, and invokes certain subjective identities to emerge from it. In order to do so, the involvement and intentionality of the participant is engaged; liturgy is not meant to be a spectator sport. To participate in a liturgy, one cannot be either intellectually or physically passive. Rather, as Macdonald says, "each person observes, selects, compares, interprets, and links information and experiences" as do the facilitators of the liturgy, the clergy, from a distinct vantage point (Macdonald 2012, p. 41). Macdonald draws a distinction between the performative and representative (or hermeneutical) analysis in which the former "is interested in what materially happens," whereas the latter "focuses on possible meanings of that which happens" (Macdonald 2012, p. 32). However, I think it is difficult to draw such a fine and neat distinction and will employ both phenomenological and hermeneutical analysis. Indeed, as Christina Gschwandtner has pointed out, it is difficult for a phenomenological analysis of liturgical experience to avoid hermeneutics entirely, as both disciplines are inherently descriptive: "Both hermeneutics and phenomenology seek to 'unfold' or depict what is 'given' in experience, what is manifested there" (Gschwandtner 2019 , p. 17). Hermeneutical understanding is necessary in order to uncover the context of texts and practices in their origins, as well as the various historical transformations and cultural contextualizations of the rituals. If hermeneutics focuses primarily on texts and contexts, phenomenology concentrates its analysis on action, practice, bodies and affect. Still both methodological approaches are necessary to give as full a description as possible: "At the most basic level, phenomenological categories are employed here for describing practices (whether observed or reported in texts) and hermeneutic ones for interpreting them, especially by setting them in relation to others or into their larger context, as the hermeneutic circle advocates" (Gschwandtner 2019, p. 18). As will be made clear once I begin the description of the Maundy Thursday liturgy, it would be impossible to gain a clear sense of what is happening without first considering the contexts and horizons of the texts of the liturgy. In this case, then, the phenomenological and hermeneutical analyses amplify and complement one another.

\section{Liturgy in the Anglican Church}

While there are points of overlap in the liturgies of different Christian denominationsresulting, as one would expect, from their common sources of origin-it is also important to clarify the specific context of the liturgy one is describing. In this case, I am considering the liturgy of Maundy Thursday as it is celebrated in the contemporary Anglican Church of Canada. In order to understand the function and understanding of liturgy, generally, in the Anglican Church, a word on the relationship between tradition and translation and between liturgy and theology is helpful.

The Faith Worship and Ministry Committee of the General Synod Anglican Church of Canada defines liturgy as follows: "Liturgy is at its heart leitourgia: a public work voluntarily undertaken by the few for the common good of all-and so Christian liturgy serves God's good purposes for us and for all of creation". ${ }^{4}$ The central importance of 
liturgy to Anglican identity requires a continual process of renewal, bringing a delicate balance between continuity and change. On the one hand, the liturgy must continue to be able to "speak" to its participants in ways that necessitate its re-interpretation and translation into different cultural contexts and languages. On the other hand, the liturgy of the Church remains grounded in the principles that are derived from creedal faith, Scripture, and the historical traditions of the church across time and different geographies.

This tension is clearly communicated in the "Introduction" to The Book of Alternative Services, which, despite the description of "Alternative" in the title, has become the primary worship text for the Anglican Church in Canada:

The gospel is truly perennial: unchanging but ever new in its confrontation and transfiguration of the world. Liturgy is the means by which the Church is constantly invested in that gospel, in the reading of the scriptures, in proclamation, in praise, in prayer of deep concern, and in those sign-acts which wordlessly incorporate the believer in the Word. Liturgy is not the gospel but it is a principal process by which the Church and the gospel are brought together for the sake of the life of the world. It is consequently vital that its form wear the idiom, the cadence, the world-view, the imagery of the people who are engaged in that process in every generation. (Anglican Church of Canada 1985, p. 10)

In other words, liturgy emerges from a dynamic interchange between a past and present-between scriptural revelation and the historical creedal confessions of the Church and the contemporary voice of Christians in the Anglican communion.

Anglican Christianity, since its origins in the sixteenth century, has held liturgy as essential to Anglican identity. The Book of Alternative Services identifies the centrality of liturgy to Anglican identity through recourse to the patristic notion of lex orandi, lex credendi:

It is precisely the intimate relationship of gospel, liturgy, and service that stands behind the theological principle lex orandi: lex credendi, i.e., the law of prayer is the law of faith. This principle, particularly treasured by Anglicans, means that theology as the statement of the Church's belief is drawn from liturgy, i.e., from the point at which the gospel and the challenge of Christian life meet in prayer. The development of theology is not a legislative process which is imposed on liturgy; liturgy is a reflective process in which theology may be discovered. (Anglican Church of Canada 1985, p. 10)

Liturgy is primary, in other words; from liturgy, theology is drawn and not vice versa. All the more reason, then, that a close phenomenological analysis of the experience of liturgy is important.

I have one final point to make generally about Anglican liturgy before I turn attention to the specific liturgy of Maundy Thursday, and that has to do with the temporality of Christian liturgy. Christian liturgy, as with all religious ritual that locates the community within a timeline for salvation or redemption, looks in two directions at once temporally: it memorializes and it anticipates. As the General Synod of the Anglican Church of Canada puts it, "it is memorial in rooting us in the historical events of God's creating and saving activity, which in turn points us forward in hope to the end of time when all we celebrate, all that is promised, comes to its fulfillment in a 'new heaven and new earth'" (FWMC 2015, p. 7) Moreover, this capacity to look both backwards and forwards in time has not only to do with salvation history, but also, on a sociological level, participation in liturgy - saying the same prayers, hearing the same scriptural readings, making the same physical movements, during the same season-offers a deep connection of people participating in the liturgy with the countless others who have followed the same liturgy in the past and will continue to do so in the future. Liturgy binds people into community, in other words, not just vertically through history, but horizontally across communities, nations, and cultures. ${ }^{5}$

Again, there is a creative tension between communion and contextualization. Ideally, the Church aims for a unity without requiring absolute uniformity on all the details. Certain 
elements of the liturgy are identified as transcultural: the scriptural readings, the recitation of the creeds, specific prayers, such as the "Our Father," baptism in the name of the Triune God, and the celebration of the Eucharist. At the same time, in the way that Jesus was born into a specific culture and historical moment, the Anglican Church recognizes the importance of contextualizing worship. Such a contextualization comes not merely through "translation" but also through "dynamic equivalence" which "involves understanding the fundamental meanings both of elements of worship and of local culture" to "re-expressing components of Christian worship with something from a local culture that has an equal meaning, value, and function" (FWMC 2015, p. 11). This enables the liturgy to be "encoded" and re-expressed in the language of local culture.

For the purposes of this analysis, my textual source will be the Book of Alternative Services which is the most common contemporary liturgical guide in the Anglican Church of Canada. Of course, beyond the unity of a common textural liturgy, there is a range of interpretations of how to enact and perform any single liturgy. In this case, I will be describing a "high" or Anglo-Catholic interpretation of the liturgy as it brings the most complex and rich material to work with. ${ }^{6}$

\section{The Liturgy of Maundy Thursday}

The name of Maundy Thursday is derived from the Latin mandatum which means commandment. Thus, the liturgy celebrates a new commandment (novum mandatum) given by Jesus in John's Gospel: "I give you a new commandment, that you love one another. Just as I have loved you, you also should love one another" (John 13:34, New Revised Standard Version). The liturgy of Maundy Thursday has three distinctive moments: the institution of the Eucharist, the washing of the feet, and preparing for vigil. Within this single liturgy, then, love is exemplified and performed within the fellowship of the Last Supper and the service of the foot-washing, while the institution of the Eucharist connects the sacrament with the approaching sacrifice of Christ's passion. Thus, the commandment of love announced in the liturgy of Maundy Thursday entails (1) fellowship—sharing a meal in gratitude and enjoyment, (2) service-caring for one another's bodies with care and humility, and (3) sacrifice-laying down one's life on the Cross.

Maundy Thursday takes place within "Holy Week" in the Anglican tradition and thus is situated within the "Paschal Cycle" celebrating the events of Christ's final meal with his disciples, his arrest and trial, crucifixion, death and resurrection as they are marked on Good Friday and Easter Sunday. It is found within the context of the larger Easter cycle, which runs from Ash Wednesday, though Lent, to Holy Week (Palm Sunday, Tenebrae, Maundy Thursday, Good Friday, and Easter). As Easter is celebrated, according to the lunar calendar, on the Sunday after the first full moon of the Spring, the Maundy Thursday which precedes it falls sometime between March 22 and April 25. From the fourth century on, the liturgy was celebrated in the evening, which already marks it as out of the ordinary. An Anglican ceremonial guide identifies the larger theme of the Easter cycle as "the salvation of the human race through the mighty acts of Jesus Christ" and says that, by participation in the liturgical celebration of this liturgical season, people "become participants in those mighty acts and enter into the risen life of Christ" (Mitchell 2007, p. xvi). The Easter season contains times for both fasting and feasting, repentance and celebration, and these polarities are brought together in a dramatic fashion within the pivotal liturgy of Maundy Thursday.

The paradoxical juxtaposition of feasting and fasting is indexed in material changes in the liturgy: first, the singing of the "Gloria," which has been absent from liturgical celebrations throughout the season of Lent, re-emerges for this one evening in celebration of the institution of the Eucharist and then disappears again for Good Friday. This tension can also be seen in the colors which the clergy are instructed to wear for their chasuble (a sleeveless outer vestment worn by priests); unusually, clergy have a choice between white-the color of celebration to be worn at Easter, Christmas and funerals (to mark the hope of resurrection) - and red-the color of martyrdom. 
Maundy Thursday has moments of celebration in the commemoration of the Last Supper, the institution of the Eucharist, and the washing of the feet. However, at a certain point, it shifts into a mood of distress and mourning, plunging the participant into the anguish of Jesus' solitary prayer in Gethsemane, his betrayal and arrest, and the abandonment of his disciples as they flee and hide to avoid arrest. The participant in the liturgy is given the opportunity to share in this complex range of emotions. Affectively, the liturgy is an emotional rollercoaster for the participants, both clergy and laity: they move through the highs of joy, gratitude, and celebration (Eucharist), through deep gestures of humility, compassion, and vulnerability (foot-washing), to the grief, loss and shame of betrayal (stripping the altar and leaving in darkness). The liturgy begins like any normal Sunday Eucharist, with a gathering of the community, a reading of Scripture, and the Eucharist, but ends unlike any other in silence and darkness. There is no official dismissal, only the chaotic stripping of the altar and a confused absence of order. Having sketched a broad outline, I will turn now to consider the separate elements and movement of the liturgy.

\subsection{Gathering and Scripture Readings}

To begin, the members of the parish, having come together from their disparate liveseach bringing their individual needs, moods, desires, and burdens- the liturgy commences with the "gathering of the community" in which the leader of the liturgy, the celebrant, greets the community with a rehearsal of what is being celebrated that evening:

This is the day that Christ the Lamb of God gave himself into the hands of those who would slay him.

This is the day that Christ gathered with his disciples in the upper room.

This is the day that Christ took a towel and washed the disciple's feet, giving us an example that we should do to others as he has done for us.

This is the day that Christ our God gave us this holy feast, that we who eat this bread and drink this cup may here proclaim his Holy Sacrifice, and be partakers of his resurrection, and at the last day may reign with him in heaven. (Anglican Church of Canada 1985, p. 304)

The entirety of the liturgy is encapsulated in these four repetitive statements- "This is the day that Christ ... "-which focus the participants' attention on the saving activity of Christ while warning of the emotional heights and depths of the celebration. These actions are reiterated in the Collect of the Day, which frames the commemoration in terms of a new commandment given by Christ, summing up the above duties of gathering, fellowship, washing and caring, and self-sacrifice through the overarching theme and command of love (Ibid).

With this greeting and collect, during which the priests and parishioners stand formally and face one another, all of the participants have been oriented towards, and prepared for, what is coming in the liturgy. The parishioners then sit in pews facing the clergy, pulpit, and altar to hear the readings from Scripture, which are designated for Maundy Thursday. Anglicans around the world will be listening to the same readings for this celebration. Hearing the same words spoken (though translated into different languages) is one of the primary points of unity, which exists both spatially across nations and cultures, and temporally, throughout different ages, connecting participants in the liturgy in a broader Christian (or more narrowly, Anglican) communion.

The first reading is the selection from the Hebrew Scriptures, Exodus 12:1-14, which tells the story of the Passover: the deliverance of the Israelite people from slavery in Egypt. It is a narrative of violence, sacrifice, and redemption, in which the Lord strikes down every firstborn child and animal in Egypt, except those staying within a house, in which the door has been marked with the blood of a sacrificed lamb. The Lord promises to "pass over" those homes to allow the Israelites to flee into the desert and return to the promised land as the rest of the inhabitants of Egypt flail in the ensuing chaos of grief. Within the Christian 
context of Maundy Thursday, this narrative serves to claim a continuity of salvation history from Ancient Israel to the coming of Jesus as the Christ. However, it also functions to bring to mind a theological claim about the sacrifice required for redemption. For those within the Christian tradition, this is both a deeply familiar story of liberation, and one that, in the details of violence, is quite shocking.

Following this reading, Psalm 116: 1, 10-17 is read, usually responsively back and forth between the leader and the people. Through the recitation of the Psalms in any liturgy, priests and laity speak together through the voice of the psalmist, offering prayers of praise, supplication, grief, or thanksgiving. Psalm 116 is a prayer of Thanksgiving, which begins with the psalmist's declaration of "delight in the Lord" for having "inclined his ear unto me" (Ps 116: 1,4) and delivered him from harm's way to safety. It is also a psalm which explicitly talks about offering to the Lord "the sacrifice of thanksgiving" and is linked to a Passover meal. Thus, within the Maundy Thursday liturgy, one already has an enfolding of time which brings a point of contact between communities: an intertextuality in the psalm, in which a Hebrew prayer commemorates an important event which is first told in the book of Exodus about the history of redemption and the covenant between the Lord and his chosen people, the Israelites, and is then recited as the psalm reading within the Christian liturgy of Maundy Thursday. Three distinct communities and moments in history have been brought together within this liturgical reading of Psalm 116.

This recitation of the psalm is followed with a reading of Paul's First Epistle to the Corinthians in which he describes Christ's institution of the Eucharist:

For I received from the Lord what I also handed on to you, that the Lord Jesus on the night when he was betrayed took a loaf of bread, and when he had given thanks, he broke it and said, "This is my body that is for you. Do this in remembrance of me." In the same way he took the cup also, after supper, saying, "This cup is the new covenant in my blood. Do this, as often as you drink it, in remembrance of me." For as often as you eat this bread and drink this cup, you proclaim the Lord's death until he comes. (1 Cor 11:23-26)

For the participants in the Christian liturgy, then, they have heard and said words which link these events, meanings, times, and communities together into a single narrative and history of salvation. Reading and hearing these texts together also implicitly functions to theologically unite an interpretation of the death of Jesus on the cross (an event that will be liturgically commemorated on Good Friday, which immediately follows Maundy Thursday) as a sacrificial and redemptive act, in the same way that the sacrifice of the lambs in Egypt enabled the liberation of the Israelites—on both cases through the saving action of God. At the same time, Paul's epistle makes clear that what is being offered through Christ's sacrifice is a "new covenant" - in continuity with, but also transformed beyond, the Exodus narrative.

The final reading of the liturgy, the Gospel reading, is singled out through a number of ritual actions which surround it. First of all, everyone stands when the time has come to hear it. The Gospel book is presented by the celebrant to the deacon and then processed into the nave-which in the architecture of the church building represents the space of the world-in order to bring the Word of God into the world and to the people. Prior to reading this Gospel passage, connection is made between the deacon and the congregants, and an invocation of divine presence to be with them: "The Lord be with you," intones the priest, to which the people respond, "And with thy spirit". Then, the deacon opens the Gospel to reveal the Word and announces the specific passage, after which both the deacon and the congregants inscribe a small cross on their foreheads, lips, and heart with their fingers. In a final act prior to the reading the deacon takes the thurible-a metal censor suspended from chains that burns incense-and censes the Gospel in a gesture of purification. Each one of these actions heightens the participants' focus and attention to the words they will hear.

For Maundy Thursday, the Gospel reading is from the Gospel of John (13: 1-17, $31 \mathrm{~b}-35)$. In this reading, one hears the story of Jesus gathering with his disciples to share a 
meal together, after which Jesus pours water into a basin and washes the feet of each of his disciples. When his disciples express hesitation about this, Jesus insists that "Unless I wash you, you have no share with me" (13:8). He goes on to explain his actions:

"Do you know what I have done to you? You call me Teacher and Lord-and you are right, for that is what I am. So if I, your Lord and Teacher, have washed your feet, you also ought to wash one another's feet. For I have set you an example, that you also should do as I have done to you. Very truly, I tell you, servants are not greater than their master, nor are messengers greater than the one who sent them. If you know these things, you are blessed if you do them ... I give you a new commandment, that you love one another. Just as I have loved you, you also should love one another. By this everyone will know that you are my disciples, if you have love for one another." (John 13: 12-17, 34-35)

From this Gospel reading, then, the liturgy receives its name (mandatum) and main theme: a new commandment for Christians to love one another with a love that begins in service and humility. The deacon processes the Gospel back to the celebrant who kisses the page and closes the book.

With this primarily textual portion of the liturgy complete, the remainder of the service takes place predominantly through liturgical action: the washing of the feet, celebration of the Eucharist, procession of the sacrament, and stripping of the altar. Likewise, we can move from a hermeneutical analysis to a more phenomenological one.

\subsection{The Washing of the Feet}

After the Scripture readings, the priest reminds the people of Christ's example by which "He taught that strength and growth in the life of the Kingdom of God come not by power, authority, or even miracle, but by such lowly service" and invites members of the congregation and "all who are so moved" to come forward "that we might recall whose servant we are" (Anglican Church of Canada 1985, p. 305). At this time, the space and focus of the liturgy shifts from the pulpit and the altar to the front of the pews in the nave, where a basin of water is placed on the chancel steps. Members of the congregation come forward to sit on a chair or stool and remove their shoes and socks, while the celebrants, carrying a towel, proceed to wash and dry the feet of their parishioners. ${ }^{7}$ Once it is washed, the priest may seal the act with a kiss to the foot of the parishioner. In many ways, this is a deeply disrupting event within the life of the parish; the controlled choreography of readings and prayers in which, for the most part, priests remain up at the altar and congregants in the pews, is changed. All of the people participating in the liturgy, clergy and laity, mingle. Bowls of water drip on the floor. Rather than donning their "Sunday finest," congregants are baring their naked feet. There is a messiness and spontaneity to this moment of the liturgy which encourages all the participants to take notice, to look a little more closely at the different details of what they are witnessing and experiencing. They may see a range of emotions play out: embarrassment and discomfort at exposing one's feet; joy and sensual pleasure of having one's body cared for and cleaned; humor and laughter with the humanity of the gesture; a seriousness in the context of the ritual; or, for the lonely or bereaved, the bittersweet release of a loving touch.

There are also differences in the details to attend to. For instance, how does one sit on a chair and remove their shoes and socks? They may be put in a neat and contained pile under their chair or they may be scattered helter-skelter. The person sitting down may be hesitant, shy, self-conscious, and nervous about the coming intimacy, or they be jovial and humorous about it. They may make eye contact with the priest kneeling before them or avoid it. The priest's touch may be light and ticklish, or firm and thorough. All these details are carefully observed, especially by the children, who understand something unusual is happening. For instance, this time of foot-washing enables the children to witness a different side of the priests, who they are used to seeing above and in front of the congregants, formally praying or blessing them, or preaching a sermon in an authoritative or meditative voice. Now, instead, they may be seen kneeling humbling, even awkwardly, 
at the feet of a respected vestry member who, too, presents an unexpected figure, who, perhaps, offers his gnarled feet with bunions, thick toenails, and a shy mischievous smile. In this way, such actions heighten everyone's attention and focuses on the body, on feet and hands touching, on skin touching and being touched, on skin used to bearing the burden of the rest of the body and unused to being touched by a stranger's hands and, thus, sensitive to the touch. There is a deep vulnerability and special intimacy in this act-both in the giving and the receiving of it. The fact that some parishes replace this ceremony with a hand-washing ritual instead bears witness to the intensity of such an experience of intimacy and vulnerability; it requires a sense of shared trust and a willingness to be physically and emotionally uncomfortable. At the same time, it is precisely the power of this disruptive intimacy which brings a "momentary levity" and a deep sense of common humanity "in the midst of a Maundy Thursday service where the congregation is otherwise preparing to mourn a death" (Macdonald 2012, p. 37).

\subsection{Eucharist and the Procession of the Sacrament}

After this unusual event, the liturgy resumes its normal Sunday rhythms and order with the celebration of the Eucharist. However, this is a particularly special celebration as it marks the first institution of the Eucharist by Jesus at the Last Supper. For this reason, at the beginning of the institution narrative, rather than say as the priest normally would, "On the night when ...," she will state "On this very night, when he was handed over to suffering and death ... " or "On this very night, when he freely gave himself to death ..." (Anglican Church of Canada 1985, p. 306). Thus, when the participants hear the words of the institution, they are brought into the memory of that specific night, re-presencing themselves with the disciples and, now too, orienting themselves in time to what is coming immediately after: a lonely and anguished night of prayer in the garden of Gethsemane and betrayal, arrest, and execution.

After the parish has participated in the Eucharist, things quiet in the building. It is evening and dark outside by this time and the church's electronic lights are dimmed so that the space is lit only by candlelight. The reserved sacrament is processed very slowly throughout the church, accompanied by the ringing of bells, to its place of vigil at the temporarily constructed altar of Gethsemane, a space filled with plants; quiet, dark and pensive. As the sacrament is carried amongst the congregation, the choir sings Bach's Passion Chorale, "O Sacred Head, Sore Wounded":

O sacred head, sore wounded,

Defiled and put to scorn;

O kingly head, surrounded

With mocking crown of thorn:

What sorrow mars Thy grandeur?

Can death Thy bloom deflow'r?

O countenance whose splendor

The hosts of heav'en adore!

Thy beauty, long desired,

Hath vanished from our sight;

Thy pow' $r$ is all expired,

And quenched the light of light.

Ah me! for whom Thou diest,

Hide not so far Thy grace:

Show me, O Love most highest,

The brightness of Thy face.

In Thy most bitter passion 
My heart to share doth cry,

With Thee for my salvation

Upon the cross to die.

Ah, keep my heart thus moved

To stand Thy cross beneath,

To mourn Thee, well-beloved,

Yet thank Thee for Thy death ...

As the priests come to a rest, they place the sacrament at the Gethsemane altar and kneel in prayer before it, before returning to the main part of the church's nave. Here, we come to the final portion of the liturgy which, again, shifts in tone dramatically from solemnity and sorrow to fear and confusion.

\subsection{Stripping of the Altar}

The altar is a symbol of Christ's body, and thus, as Christ was arrested, stripped, and brought to his place of execution, so too, the altar is stripped of its fineries and hastily washed with wine as one would anoint a body for burial. The space and energy changes quite starkly. The careful order and choreography of the movement and positions of the clergy - their Pseudo-Dionysian performance of ecclesial (and celestial) hierarchies-is explicitly replaced with unplanned, chaotic, rushed, and messy movement hither and yon, as the priests frantically set up stripping the altar of its linens and ornaments. Wine is sloppily poured over the altar and quickly wiped with a cloth. Priests rush to extinguish the candles on the altar and throughout the building and carry them away. As a result, the church is plunged into darkness and the clergy bump into pews and the altar railing in their haste. The space of the church has become dark and noisy, confusing, and destabilizing.

The affective result of this for all the participants is one of unsettlement and fear. The priests offer no comfort; they, like the disciples in the garden of Gethsemane, flee in panic at Christ's arrest. The turmoil and chaos are intentional, signifying and giving all the participants a sense of the chaos that takes over in the absence of the beauty and order of the Word. It catapults the participant into the experience of the coming event of Good Friday and the sacrifice on the Cross. Thus, here, at the end of the Maundy Thursday liturgy, which has celebrated God's presence in the institution of the Eucharist, and Christ's love in the humble care for the bodies of his disciples in the foot-washing, the participant is finally thrust into an encounter with the absence of the Word of God. The order of the universe is breaking down. No dismissal or blessing is given by the priests to the congregants. They, too, leave in silence, confusion, and without closure. The liturgy refuses to grant a resolution to the crisis; it simply leaves the participant in that moment of grief, fear, perplexity, and remorse. The liturgy is over and the vigil for Good Friday begins.

\section{Conclusions}

The Maundy Thursday liturgy is unusual in its dramatic affective range which a phenomenological analysis can uncover. Part joyous celebration and part deep lament, the liturgy encompasses the breadth of the entire Easter season and, indeed, the Christian story of redemption. In a short period of time it, not only textually connects the contemporary Christian with their Israelite and early Christian forebearers, but it provides an opportunity to affectively participate in joy and thanksgiving, kindness and compassion, care for the body, attention to the vulnerable, as well as the fear, confusion and remorse of betrayal and arrest. It serves as an excellent example of the rich complexity and depth which is functioning in liturgy. However, in order to begin to get a sense of this complexity, one needs to move beyond a theological and hermeneutical interpretation of the meaning of the liturgy to a phenomenological analysis. Phenomenology enables one to be attentive to the temporality and spatiality of the actions and movements of the liturgy to get a sense of the communal structures-the relationality and embodiment of the liturgy and, finally, 
to begin to have some understanding of the complex affective impacts of the liturgy on its participants.

Funding: This research received no external funding.

Conflicts of Interest: The author declares no conflict of interest.

\section{Notes}

1 It also differs from Emmanuel Falque's richly detailed phenomenological meditation on the experience of the Triduum-Maundy Thursday, Good Friday and Easter-in so far as I direct my attention primarily, and solely, to the lived experience of the actual liturgy of Maundy Thursday, rather than seeing it as a lens through which to understand the human experience of eating, desire, service, death, suffering, betrayal, etc. For the latter, see (Falque 2016).

2 Rowan Williams has argued that the actions are more important than the objects-the latter are imbued with sacredness only through the actions of participant: “ ... the primary concern should be for sacramental actions rather than an attempt to focus on 'sacralized' objects" (see Rowan 2000). While I think that Williams is correct in this statement, it does not follow that the sacramental objects are not significant or worthy of attention themselves. In this essay, while my primary focus will be on actions, I will remain attentive to the objects used in liturgical action.

3 See Gschwandtner: "Thus, a phenomenology of liturgical experience can depict how liturgy opens a world, how space and time are experienced within it and shape its experience, how bodies move within liturgy and how they are affected by liturgy's appeal to the senses and the emotions, how personal and communal experience interact with and shape each other" (28).

4 Faith Worship and Ministry Committee (FWMC) of the General Synod Anglican Church of Canada, Liturgical Principles: principles to guide the revision of contemporary language common worship texts of the Anglican Church of Canada: https: / / www.anglican.ca/resources/liturgical-principles (accessed on 5 July 2021).

5 We can observe that the unity of the Anglican communion, then, is founded not on a single leader as with the Catholic Church, or on Scripture or a certain doctrine as in other Protestant denominations but in the liturgy. It is for this reason that, in the past few decades, division and internal debates within the global Anglican communion have occurred over questions that are fundamentally liturgical: who can be ordained to celebrate the liturgy, and to whom is the liturgy of the celebration of marriage accessible? These debates do not simply articulate different political or social positions; they are fought over passionately because they entail significantly different visions of liturgical worship.

6 In the following analysis I am deeply indebted to the observations and insight of Rev. Dr. Travis O'Brian, the Rector of St. Barnabas Anglican Church in Victoria, BC, Canada. St. Barnabas is a parish in the Anglo-Catholic tradition and this description of the liturgy reflects that identity.

7 In some congregations, this becomes a reciprocal and inclusive affair whereby celebrants and congregants have their feet washed and wash another's in turn. This brings a similar experience of service, humility, and vulnerability but strengthens the fluidity of roles between servant and teacher, carer and cared for.

\section{References}

Anglican Church of Canada. 1985. The Book of Alternative Services of the Anglican Church of Canada with the Revised Common Lectionary. Toronto: Anglican Book Centre.

Falque. 2016. The Wedding Feast of the Lamb: Eros, the Body, and the Eucharist. Translated by George Hughes. New York: Fordham University Press.

Faith Worship and Ministry Committee (FWMC) of the General Synod Anglican Church of Canada. 2015. Liturgical Principles: Principles to Guide the Revision of Contemporary Language Common Worship Texts of the Anglican Church of Canada. Available online: https:/ / www.anglican.ca/resources/liturgical-principles (accessed on 5 July 2021).

Gschwandtner, Christina M. 2019. Welcoming Finitude: Toward a Phenomenology of Orthodox Liturgy. Orthodox Christianity and Contemporary Thought Series; New York: Fordham University Press.

Macdonald, Megan. 2012. Mass Performance: How Material Liturgies Enact the Spiritual. Liturgy 28: 31-42. [CrossRef]

Mitchell, Leonel L. 2007. Lent, Holy Week, Easter and the Great Fifty Days: A Ceremonial Guide. Lanham: Cowley Publications.

Rowan, Williams. 2000. The Nature of a Sacrament. In On Christian Theology. Oxford: Blackwell, p. 205. 